\title{
Patenting Stem Cell Technologies in Europe
}

\author{
Andrew Sheard \\ Andrew Sheard Patent Attorney, Berkhamsted, Hertfordshire HP4 1PP, United Kingdom \\ Correspondence: ags@andrew-sheard.com
}

European patent law as it applies to stem cell technologies is complex. The complexities have developed from different supranational sources of law during the last 50 years and from the various levels of exceptions to patentability embodied in the law. In relation to stem cells of human embryonic origin, the definition of a human embryo, although broad, is still in some respects unclear; and the definition of what constitutes the use of a human embryo for industrial or commercial purposes, which is excluded from patentability in Europe, is also remarkably broad. Further clarification is awaited from the courts and from the Boards of Appeal of the European Patent Office.

$T_{t}^{o}$ understand how patent law in Europe treats stem cell technologies today, it is necessary to see how the different sources of law have interacted with each other to give rise to the present position.

It has been a little more than 50 years since the Convention on the Unification of Certain Points of Substantive Law on Patents for Invention was adopted in Strasbourg on November 27, 1963, by member states of the Council of Europe. ${ }^{1}$ The Strasbourg Convention, as it became known, marked the first serious attempt to harmonize the patent laws of European countries and provided the foundation of much of

\footnotetext{
${ }^{1}$ The Council of Europe (www.coe.int) is an international organization distinct from, and not to be confused with, the EU or any of its institutions, which include the nearly identically named European Council. The Council of Europe was set up in the aftermath of the Second World War to promote democracy and protect human rights and the rule of law in Europe. The European Patent Organisation, of which the European Patent Office (EPO) is part, is separate again.
}

today's substantive law in Europe on patentability, ${ }^{2}$ including the exceptions to patentability. One of these exceptions is to be found in Article 2(a) of the Strasbourg Convention:

The Contracting States shall not be bound to provide for the grant of patents in respect of:

(a) inventions the publication or exploitation of which would be contrary to ordre public or morality, provided that the exploitation shall not be deemed to be so contrary merely because it is prohibited by a law or regulation;...

That exception has ultimately framed the law that we have today, in its complex and still evolving state. As we shall see, the operation of the exception is paradoxical; it is in some respects curiously broad in its reach, involving as it does a

\footnotetext{
${ }^{2}$ Of course, all inventions relating to stem cell technologies must meet the fundamental requirements of patentability contained in Article 52(1) EPC (novelty, inventive step, and industrial applicability) in addition to escaping any applicable exceptions to patentability.
}

Editors: Salim Mamajiwalla and Rochelle Seide

Additional Perspectives on Intellectual Property in Molecular Medicine available at www.perspectivesinmedicine.org

Copyright (C) 2015 Cold Spring Harbor Laboratory Press; all rights reserved; doi: 10.1101/cshperspect.a021089

Cite this article as Cold Spring Harb Perspect Med 2015;5:a021089 


\section{A. Sheard}

new approach to assessing patentability, yet despite that, its impact as far as concerns stem cell technologies is essentially only on stem cells of a particular origin, namely, those derived from the embryo, particularly the human embryo.

\section{DEVELOPMENT OF THE LAW}

\section{The Early Years}

In its original form the European Patent Convention (EPC) was agreed on in 1973 (EPC 1973) and entered into force in the founder contracting states in late 1977, shortly before the European Patent Office (EPO) opened on June 1,1978 . The exception to patentability corresponding to Article 2(a) of the Strasbourg Convention is found in almost identical terms in Article 53(a) EPC 1973:

Exceptions to patentability

European patents shall not be granted in respect of:

(a) inventions the publication or exploitation of which would be contrary to "ordre public" or morality, provided that the exploitation shall not be deemed to be so contrary merely because it is prohibited by law or regulation in some or all of the Contracting States;...

In the 1990s case law began to put flesh on the bones of this exception. Although T 49/83 (Propagating material/CIBA GEIGY) (OJ EPO 1984,112 ) had stated that no general exclusion of inventions in the sphere of animate nature could be inferred from EPC 1973, T 19/90 (OncoMouse/HARVARD) (OJ EPO 1992, 588), concerning the transgenic OncoMouse, was the first to deal squarely with ethical issues under Article 53(a) EPC 1973. In applying an early and repeatedly adopted principle from T 320/87 ( $H y$ brid plants/LUBRIZOL) (OJ EPO 1990, 76) and other cases that any such exception to patentability must be narrowly construed, ${ }^{3}$ the board decided that transgenically modified animals could in principle be patented.

T 356/93 (Plant cells/PLANT GENETIC SYSTEMS) (OJ EPO 1995, 545) addressed the

\footnotetext{
${ }^{3}$ A principle significantly eroded by later cases, including $\mathrm{G}$ 2/06 - see below-and G 1/07 (Treatment by surgery/ MEDI-PHYSICS) (OJ EPO 2011, 134).
}

question of ordre public as well as morality in the following terms:

5. It is generally accepted that the concept of "ordre public" covers the protection of public security and the physical integrity of individuals as part of society. This concept encompasses also the protection of the environment. Accordingly, under Article 53(a) EPC [1973], inventions the exploitation of which is likely to breach public peace or social order (for example, through acts of terrorism) or to seriously prejudice the environment are to be excluded from patentability as being contrary to "ordre public."

6. The concept of morality is related to the belief that some behaviour is right and acceptable whereas other behaviour is wrong, this belief being founded on the totality of the accepted norms which are deeply rooted in a particular culture. For the purposes of the EPC, the culture in question is the culture inherent in European society and civilisation. Accordingly, under Article 53(a) EPC [1973], inventions the exploitation of which is not in conformity with the conventionally-accepted standards of conduct pertaining to this culture are to be excluded from patentability as being contrary to morality.

If any cases related to stem cell technologies had come before the EPO Boards of Appeal in the 1990s, they would have been argued and decided on the basis of this general guidance. However, there was to be a major development in the law at the end of the decade.

\section{From the General to the Particular}

During the 1990s, the institutions of the European Union (EU) had been examining the legal protection of biotechnological inventions, and the result, eventually, was Directive 98/44/EC of July 6, 1998, ${ }^{4}$ widely known as the Biotech Directive. The purposes and history of the Biotech Directive have been discussed in detail elsewhere (Kamstra et al. 2002), but one of its aims was to introduce greater certainty into the ordre public/morality exception to patentability. Article 6 of the directive begins with the

${ }^{4}$ Directive 98/44/EC of the European Parliament and of the Council of 6 July 1998 on the legal protection of biotechnological inventions (OJ EC L 213/13) (30.7.98). 
now familiar words derived from Article 2(a) of the Strasbourg Convention and then particularizes instances of inventions falling within the exception:

1. Inventions shall be considered unpatentable where their commercial exploitation would be contrary to ordre public or morality; however, exploitation shall not be deemed to be so contrary merely because it is prohibited by law or regulation.

2. On the basis of paragraph 1 , the following, in particular, shall be considered unpatentable:

(a) processes for cloning human beings;

(b) processes for modifying the germ line genetic identity of human beings;

(c) uses of human embryos for industrial or commercial purposes;

(d) processes for modifying the genetic identity of animals which are likely to cause them suffering without any substantial medical benefit to man or animal, and also animals resulting from such processes.

Article 6(2)(c), with which we are principally concerned, needs to be read in the context of the recitals, including recitals $16,20,21$, and 42 , of the Biotech Directive:

(16) Whereas patent law must be applied so as to respect the fundamental principles safeguarding the dignity and integrity of the person; whereas it is important to assert the principle that the human body, at any stage in its formation or development, including germ cells, and the simple discovery of one of its elements or one of its products, including the sequence or partial sequence of a human gene, cannot be patented; whereas these principles are in line with the criteria of patentability proper to patent law, whereby a mere discovery cannot be patented;

(20) Whereas, therefore, it should be made clear that an invention based on an element isolated from the human body or otherwise produced by means of a technical process, which is susceptible of industrial application, is not excluded from patentability, even where the structure of that element is identical to that of a natural element, given that the rights conferred by the patent do not extend to the human body and its elements in their natural environment;
(21) Whereas such an element isolated from the human body or otherwise produced is not excluded from patentability since it is, for example, the result of technical processes used to identify, purify and classify it and to reproduce it outside the human body, techniques which human beings alone are capable of putting into practice and which nature is incapable of accomplishing by itself;

(42) Whereas, moreover, uses of human embryos for industrial or commercial purposes must also be excluded from patentability; whereas in any case such exclusion does not affect inventions for therapeutic or diagnostic purposes which are applied to the human embryo and are useful to it.

An EU directive such as the Biotech Directive does not itself have direct legal effect as far as its provisions are concerned. Rather, a directive is an instruction to member states of the EU to adapt their law by appropriate legislative means to achieve the results specified in the directive. The European Patent Organisation, which as previously noted is separate from the EU, was under no obligation to make any legislative adaptation of its own, but the EPO's Administrative Council nevertheless decided in 1999 to adapt the Implementing Regulations to the EPC (the EPC Rules), in view of the large overlap between EU member states and EPC contracting states (Table 1).

Shortly after this change to the EPC Rules, a revision to the EPC itself was agreed on by the contracting states. EPC 2000, as the revised text became known, eventually entered into force in 2007 and adjusted Article 53a partly in compliance with the TRIPs Agreement ${ }^{5}$ to limit the exception to patentability to only those inventions whose commercial exploitation was contrary to law or morality-mere publication of the invention or noncommercial exploitation were no longer issues. EPC 2000 also caused some changes in the numbering of the EPC Rules that the Administrative Council implemented for conformity with the Biotech Directive, so Article 53a EPC and certain of its attendant rules are now as follows:

\footnotetext{
${ }^{5}$ Agreement on Trade-Related Aspects of Intellectual Property Rights signed at Marrakesh on April 15, 1994 (the TRIPs Agreement).
} 
A. Sheard

Table 1. European Patent Convention (EPC) contracting states and European Union (EU) member states

\begin{tabular}{|c|c|c|c|}
\hline Code & Country & $\begin{array}{l}\text { EPC member } \\
\text { since }\end{array}$ & $\begin{array}{l}\text { EU member } \\
\text { since }\end{array}$ \\
\hline $\mathrm{AL}$ & Albania & 2010 & - \\
\hline AT & Austria & 1979 & 1995 \\
\hline $\mathrm{BE}$ & Belgium & 1977 & 1952 \\
\hline BG & Bulgaria & 2002 & 2007 \\
\hline $\mathrm{CH}$ & Switzerland & 1977 & - \\
\hline $\mathrm{CY}$ & Cyprus & 1998 & 2004 \\
\hline $\mathrm{CZ}$ & Czech Republic & 2002 & 2004 \\
\hline DE & Germany & 1977 & 1952 \\
\hline DK & Denmark & 1990 & 1973 \\
\hline $\mathrm{EE}$ & Estonia & 2002 & 2004 \\
\hline ES & Spain & 1986 & 1986 \\
\hline FI & Finland & 1996 & 1995 \\
\hline FR & France & 1977 & 1952 \\
\hline GB & United Kingdom & 1977 & 1973 \\
\hline GR & Greece & 1986 & 1981 \\
\hline HR & Croatia & 2008 & 2013 \\
\hline $\mathrm{HU}$ & Hungary & 2003 & 2004 \\
\hline IE & Ireland & 1992 & 1973 \\
\hline IS & Iceland & 2004 & - \\
\hline IT & Italy & 1978 & 1952 \\
\hline LI & Liechtenstein & 1980 & - \\
\hline LT & Lithuania & 2004 & 2004 \\
\hline $\mathrm{LU}$ & Luxembourg & 1977 & 1952 \\
\hline LV & Latvia & 2005 & 2004 \\
\hline MC & Monaco & 1991 & - \\
\hline MK & $\begin{array}{l}\text { Former Yugoslav } \\
\text { Republic of } \\
\text { Macedonia }\end{array}$ & 2009 & - \\
\hline MT & Malta & 2007 & 2004 \\
\hline NL & Netherlands & 1977 & 1952 \\
\hline NO & Norway & 2008 & - \\
\hline PL & Poland & 2004 & 2004 \\
\hline PT & Portugal & 1992 & 1986 \\
\hline RO & Romania & 2003 & 2007 \\
\hline RS & Serbia & 2010 & - \\
\hline SE & Sweden & 1978 & 1995 \\
\hline SI & Slovenia & 2002 & 2004 \\
\hline SK & Slovakia & 2002 & 2004 \\
\hline SM & San Marino & 2009 & - \\
\hline TR & Turkey & 2000 & - \\
\hline
\end{tabular}

Exceptions to patentability

European patents shall not be granted in respect of:

(a) inventions the commercial exploitation of which would be contrary to "ordre public" or morality; such exploitation shall not be deemed to be so contrary merely because it is prohibited by law or regulation in some or all of the Contracting States;...

Rule 26

General and definitions

(1) For European patent applications and patents concerning biotechnological inventions, the relevant provisions of the Convention shall be applied and interpreted in accordance with the provisions of this Chapter. Directive 98/44/EC of 6 July 1998 on the legal protection of biotechnological inventions shall be used as a supplementary means of interpretation....

Rule 28

Exceptions to patentability

Under Article 53(a), European patents shall not be granted in respect of biotechnological inventions which, in particular, concern the following:

a) processes for cloning human beings;

b) processes for modifying the germ line genetic identity of human beings;

c) uses of human embryos for industrial or commercial purposes;

d) processes for modifying the genetic identity of animals which are likely to cause them suffering without any substantial medical benefit to man or animal, and also animals resulting from such processes.

\section{The Particular Case of Human Embryonic Stem Cells}

From the above survey of the multistranded development of the current primary and secondary legislation, it can be seen that there is no legislated exception to patentability that necessarily covers all stem cells. Cell lines are patentable in principle, and nothing excludes human cell lines in general from patentability; in fact, recitals 20 and 21 of the Biotech Directive, quoted above, tend to confirm their patentability in principle. The fact that a particular cell line is, at least to some degree, undifferentiated does not of itself affect the general position unless it falls foul of one of the particularized exceptionsthe most relevant of which is in Rule 28(c) EPC, 
namely, "uses of human embryos for industrial or commercial purposes." So we can say that nonhuman stem cells, even if embryonic in origin, will not be caught by this particular exception. Neither will nonembryonic stem cells (including adult stem cells, amniotic stem cells, and induced pluripotent stem cells), whose use is less controversial than that of cells derived from the embryo. This is not to say that all inventions involving nonhuman stem cells ${ }^{6}$ or human stem cells that are nonembryonic in origin-will necessarily avoid the exception from patentability by Article 53a EPC: The general nature of that exception remains, so it is open to parties (or examiners) to argue on a case-by-case basis that individual circumstances trigger the ordre public/morality exception even if those circumstances are not particularized in the rules.

But how does the law in Europe treat stem cells that are derived from human embryos? Two questions in particular arise: What precisely is meant by an "embryo" in this context? And in what circumstances does the "use" of the human embryo cause the exception to be triggered to preclude patentability? Both have been addressed in various decisions, essentially causing the exception to be construed remarkably broadly, but fundamental questions remain unanswered.

\section{What Is an "Embryo"?}

In the decision of the Enlarged Board of Appeal of the EPO in case G 2/06 (Use of embryos/ WARF) (OJ EPO 2009, 306) dated November 28, 2008, the Enlarged Board was urged by the appellant to adopt a specific meaning of "embryo" (as being embryos of 14 days or older) in accordance with usage in the medical field. The Enlarged Board rejected this argument, noting that both German and U.K. law had legislated that the term "embryo" includes embryos youn-

\footnotetext{
${ }^{6}$ In relation to the question of whether nonhuman animal embryos may still be caught by the general ordre public/ morality exception, note that recital 38 of the Biotech Directive states, "... .whereas. . .totipotent cells of humans and animals, are obviously also excluded from patentability" (emphasis added).
}

ger than 14 days, $^{7}$ and the legislators must presumably have been aware of these definitions used in national laws and yet chose to leave the term undefined. Further, because the purpose of the law enshrined in the Biotech Directive (and Rule 28 EPC) is to protect human dignity and prevent the commercialization of embryos (recitals 16 and 42), the Enlarged Board deduced that "embryo" was not to be given any restrictive meaning. "What is an embryo," it added, "is a question of fact in the context of any particular patent application" (G 2/06 20).

A subsidiary issue in $\mathrm{G} 2 / 06$ was a request by the appellant for a preliminary ruling by what was then the European Court of Justice (ECJ) - now the Court of Justice of the European Union (CJEU) — which was held inadmissible on jurisdictional grounds. However, it was not long before the ECJ came to examine the issue on a reference from a national court, the German Bundesgerichtshof (BGH), in case C34/10 (Brüstle v Greenpeace). Like the Enlarged Board of Appeal of the EPO, the CJEU decided that the term "embryo" was to be interpreted broadly:

35 Accordingly, any human ovum must, as soon as fertilised, be regarded as a "human embryo" within the meaning and for the purposes of the application of Article 6(2)(c) of the Directive, since that fertilisation is such as to commence the process of development of a human being.

36 That classification must also apply to a nonfertilised human ovum into which the cell nucleus from a mature human cell has been transplanted and a non-fertilised human ovum whose division and further development have been stimulated by parthenogenesis. Although those organisms have not, strictly speaking, been the object of fertilisation, due to the effect of the technique used to obtain them they are...capable of commencing the process of development of a human being just as an embryo created by fertilisation of an ovum can do so.

\footnotetext{
${ }^{7}$ The German Gesetz zum Schutz von Embryonen of December 13, 1990, \$8 defines “embryo" as including a fertilized egg, and the UK Human Fertilisation and Embryology Act $1990, \$ 1(1)$, defines "embryo" as including the two-cell zygote and an egg in the process of fertilization-G 2/06 $₫ 20$.
} 


\section{A. Sheard}

And also like the EPO Enlarged Board, the CJEU declined to decide whether the subject matter of the case at hand involved an "embryo," instead holding that:

37 As regards stem cells obtained from a human embryo at the blastocyst stage, it is for the referring court to ascertain, ${ }^{8}$ in the light of scientific developments, whether they are capable of commencing the process of development of a human being and, therefore, are included within the concept of "human embryo" within the meaning and for the purposes of the application of Article $6(2)(c)$ of the Directive.

The CJEU's test, focusing as it does on an embryo's capability of "commencing the process of development of a human being," still left unresolved issues. In International Stem Cell Corporation $v$ Comptroller General of Patents (2013) (EWHC 807), the Patents Court (part of the High Court of England and Wales) was asked to choose between two interpretations of the test:

3.... Does that contemplate the commencement of a process which must be capable of leading to a human being? Or does it contemplate the commencement of a process of development, even though the process cannot be completed, so that it is incapable of leading to a human being?

The case concerned the production of pluripotent human stem cell lines from parthenogenetically activated oocytes (parthenotes), which are capable of developing into blastocyst-like structures comprising trophectoderm and an inner cell mass. However, they cannot develop to term. The judge was inclined to hold that such pluripotent cells that are incapable of leading to a human being should not be excluded

\footnotetext{
${ }^{8}$ What in fact happened when the case came back to the referring court (as Neurale Vorläuferzellen II, X ZR 58/07) was that the BGH held that obtaining stem cells from embryos, according to the understanding of the skilled person at the priority date, is typically linked with the destruction of the embryo. Although this meant that the claims as granted were not valid, the BGH did allow an auxiliary request in which the claims were limited by a proviso, expressed in claim 1 in the following terms:

"... wherein no isolated purified precursor cells from human embryonic stem cells are encompassed during the generation of which embryos have been destroyed."
}

from patentability (as opposed to totipotent cells, which he would exclude ${ }^{9}$ ). He reached this view on the basis that the Biotech Directive is seeking to balance, on the one hand, the encouragement of research in the field of biotechnology by means of the patent system and, on the other hand, the need to respect the fundamental principles safeguarding the dignity and integrity of the person; and excluding processes of development that are incapable of leading to a human being did not, in his view, strike a balance at all. Furthermore, the judge considered that the BGH's comment that "According to the decision of the Court of Justice, an embryo has to be regarded as an organism exhibiting the faculty of starting the process of the development of a human being" (Reasons \$III.3.a 2) was supportive of his view.

Nonetheless, because he considered that there was sufficient doubt as to the precise meaning of the ruling in C-34/10 (Brüstle), he did not decide the issue but referred the following question to the CJEU:

Are unfertilised human ova whose division and further development have been stimulated by parthenogenesis, and which, in contrast to fertilised ova, contain only pluripotent cells and are incapable of developing into human beings, included in the term "human embryos" in Article $6(2)$ (c) of Directive 98/44/EC on the legal protection of biotechnological inventions?

At the time of going to press, the CJEU's decision (case C-364/13) is awaited, although Advocate General Cruz Villalón's recently issued opinion is that an ovum whose development has been stimulated without fertilization and that is not capable of becoming a human being cannot be considered a human embryo-and is therefore patentable in principle. However, the Advocate General considered if this ovum is genetically manipulated in such a way that it can develop into a human being, it must be regarded as a human embryo and as such excluded from patentability. The Court is not bound to accept

\footnotetext{
${ }^{9}$ Consistent with recital 38 of the Biotech Directive: "... whereas... totipotent cells of humans and animals, are obviously also excluded from patentability."
} 
the Advocate General's opinion, although it often does.

\section{"Use" of a Human Embryo}

The question of what constitutes the use of a human embryo for an industrial or commercial purpose within the meaning of Article 6(2)(c) of the Biotech Directive and Rule 28(c) EPC is another major issue. Recital 42 of the Biotech Directive, quoted above, emphasized that "uses of human embryos for industrial or commercial purposes must also be excluded from patentability" - wording reflected verbatim in Article (6) (2) (c) - but went on to state that "such exclusion does not affect inventions for therapeutic or diagnostic purposes ${ }^{10}$ which are applied to the human embryo and are useful to it." This apparently benign attempt at clarifying that a diagnostic or therapeutic invention for the embryo's benefit is not to be excluded from patentability has a significance beyond its apparent simplicity: It was taken by the Enlarged Board of the EPO in G 2/06 to signal that if an embryo is destroyed in the production of stem cells, then that cannot have been to the benefit of the embryo and that an invention that involves the destruction of an embryo must be excluded from patentability. As the Enlarged Board put it:

25. A claimed new and inventive product must first be made before it can be used. Such making is the ordinary way commercially to exploit the claimed invention and falls within the monopoly granted, as someone having a patent application with a claim directed to this product has on the grant of the patent the right to exclude others from making or using such product. Making the claimed product remains commercial or industrial exploitation of the invention even where there is an intention to use that product for further research. On the facts which this Board must assume in answering the referred question 2, making the claimed product involves the destruction of human embryos. This use involving destruction is thus an integral and essential part

\footnotetext{
${ }^{10}$ Inventions for therapeutic or diagnostic purposes are themselves something of a legal minefield in Europe in view of Article 53(c) EPC, but that topic is beyond the scope of this article.
}

of the industrial or commercial exploitation of the claimed invention, and thus violates the prohibition of Rule 28(c) (formerly 23d(c)) EPC [G 2/06 25].

Nonetheless, the enquiry in G 2/06 as to whether a human embryo was necessarily destroyed was relatively narrow, in that it looked only at the making of the claimed invention. If alternative sources of cell lines were available, the invention was not excluded from patentability even if an embryo had been destroyed, so the initial practice following G 2/06 was relatively liberal. The then in-force U.K. Intellectual Property Office Biotechnology Examination Guidelines (April 2009) ${ }^{11}$ put it this way:

111. Since [G 2/06], there have been a number of advances in this area, in particular in relation to the proliferation and storage of hESC [human embryonic stem cell] lines, and therefore to exploit any subsequent invention, a person skilled in the art can rely upon the existence of hESC lines, and will not have to resort to the destruction of a human embryo. For this reason, the Intellectual Property Office has decided to continue to grant patents for those hESC lines that, at the filing date, could be obtained [by] means other than the destruction of a human embryo.

But this liberality was short-lived. The CJEU in Brüstle (C-34/10) held that the origin of those cell lines must also be examined:

49 ...The fact that destruction may occur at a stage long before the implementation of the invention, as in the case of the production of embryonic stem cells from a lineage of stem cells the mere production of which implied the destruction of human embryos is, in that regard, irrelevant.

Following that, the U.K. Intellectual Property Office tightened its practice. The current Practice Note, issued May 17, 2012, states:

... Office practice will now recognise that where the implementation of an invention requires the use of cells that originate from a process which requires the destruction of a human embryo, the invention is not patentable...For example,

\footnotetext{
${ }^{11}$ Examination Guidelines for Patent Applications relating to Biotechnological Inventions in the Intellectual Property Office (April 2009).
} 


\section{A. Sheard}

where the implementation of the invention requires the use of a human embryonic stem cell line the establishment of which originally required the destruction of a human embryo, the invention is not patentable.

On a practical level, it is noted (Schlich 2013; Schlich and Hill 2013) that the EPO now accepts that the first date on which hESC lines can be derived without destroying an embryo is January 10,2008 , the publication date of Chung et al. (2008), who report that they:

clearly show that hESC lines can be derived without embryo destruction and that the biopsy procedure did not appear to interfere with subsequent good blastocyst development of the parent embryo. These results were achieved without culturing multiple blastomeres together, and at an efficiency substantially higher $(20 \%$ or $50 \%$ versus $2 \%$ ) than in our previous report. The success rate of this new procedure is similar to that of conventional hESC derivation techniques using blastocysts. In addition, we show that hESC coculture is not an essential part of the derivation procedure. ${ }^{12}$

So for patent applications whose filing date (or, as the case may be, priority date) is after January 10, 2008, the prospects for patenting human embryo-derived stem cell technologies are, in this respect, a little brighter. But we still await guidance from the EPO Boards of Appeal.

It has been cogently argued (Schlich 2013; Schlich and Hill 2013) that human embryonic cell lines have tended to be derived from spare embryos originating from in vitro fertilization (IVF) treatment and are either donated, deemed to be of too poor a quality for IVF use, or surplus to requirements, none of which could reasonably be said to be "uses of human embryos for industrial or commercial purposes," and the destruction of these embryos would have happened anyway even if no stem cell lines had been derived from them. Rightly or wrongly, though, the Enlarged Board and the CJEU chose to adopt a broader construction of the exclusion-it seems as if the "industrial or commercial purpose" of the patent system itself can

\footnotetext{
${ }^{12}$ Page 116 , middle column.
}

be enough to trigger the exception to patentability.

A further instance of a broad construction of the exception to patentability embodied in Rule 28(c) EPC is seen in the willingness of the Enlarged Board in G 2/06 to look beyond what is actually claimed to some undefined concept of "the invention"-despite the fact that for most purposes of patent law the claims define the invention:

21. Secondly, the Appellant contends that, in order to fall under the prohibition of Rule 28(c) (formerly $23 \mathrm{~d}(\mathrm{c})$ ) EPC, the use of human embryos must be claimed.

22. However, this Rule (as well as the corresponding provision of the Directive) does not mention claims, but refers to "invention" in the context of its exploitation. What needs to be looked at is not just the explicit wording of the claims but the technical teaching of the application as a whole as to how the invention is to be performed. Before human embryonic stem cell cultures can be used they have to be made. Since in the case referred to the Enlarged Board the only teaching of how to perform the invention to make human embryonic stem cell cultures is the use (involving their destruction) of human embryos, this invention falls under the prohibition of Rule 28(c) (formerly $23 \mathrm{~d}(\mathrm{c})$ ) EPC (compare also the decision of the BPatG of 5 December 2006, loc.cit., points IV 2.1 to 2.3 [Oliver Brüstle v. Greenpeace e.V. C-34/10 (2012) 1 CMLR 41]). To restrict the application of Rule 28(c) (formerly $23 \mathrm{~d}(\mathrm{c})$ ) EPC to what an applicant chooses explicitly to put in his claim would have the undesirable consequence of making avoidance of the patenting prohibition merely a matter of clever and skilful drafting of such claim [G 2/06 21-22].

Two cases illustrate that EPO practice is far from straightforward, especially for applications and patents having a filing (or priority) date on or before the publication date of Chung et al. (2008). Not only is "use for industrial or commercial purposes" still being interpreted broadly, but also patentability is hard to restore by a disclaiming amendment, at least if the amendment does not have basis in the application as filed. 
First, T 1836/10 (Gewinnung von embryonalen Stammzellen/WÜRFEL) (not published in OJ EPO) was recently decided by Technical Board 3.3.08 on appeal from the examining division. The underlying application (which had a 2005 filing date) was directed to a process for recovering pluripotent embryonic stem cells from a blastocyst without destroying the embryo. A claim to such a process was considered to contravene Rule 28(c) EPC because it was use of the embryo for industrial or commercial purposes (and not saved by being for the benefit of the embryo). Furthermore, the applicant's attempt to introduce a disclaimer to the excluded matter came to nothing. One attempt at the language chosen for the disclaimer was "with the proviso that, in the case where the blastocyst is a human blastocyst, the cells obtained are supplied for no industrial or commercial use." Although this language was not present in the application as filed, the Enlarged Board in G 1/ 03 (Disclaimer/PPG) (OJ EPO 2004, 413) had held that an undisclosed disclaimer could in principle be used, without offending against the prohibition against adding new subject matter, to disclaim something excluded from patentability by, among other provisions, Article 53a EPC (and hence Rule 28(c) EPC). In the present case, however, the board decided that subject matter was added by the disclaimer, essentially because there was a mismatch of categories between the claim on the one hand (which related to a process for recovering pluripotent embryonic stem cells from a blastocyst) and the proviso on the other hand (which related to the intended use of the stem cells so obtained): Because an intended future use of the stem cells was not part of the process for preparing them, the use could not be disclaimed from the process.

The second case is T 2221/10 (Culturing stem cells/TECHNION) (not published in OJ EPO), also recently decided ex parte by Technical Board 3.3.08. The underlying application had an even earlier filing date, in 2003, and was directed to a method of maintaining hESCs in an undifferentiated state either by coculturing the hESCs with a human foreskin feeder cell line or by culturing the hESCs in the presence of conditioned medium enriched with human foreskin-secreted factors. Because the ways in which the application disclosed that hESCs could be obtained all involved either destruction of a human embryo de novo or use of an existing hESC line that itself was obtained by the destruction of a human embryo, the invention was held to involve the use of a human embryo and hence was excluded from patentability under Article 53(a) EPC in combination with Rule 28(c) EPC. In reaching its decision, the board considered the decision of the CJEU in Brüstle (C-34/10) and noted with apparent approval that, although judgments of the CJEU are not legally binding on the EPO or its Boards of Appeal, they should be considered as being persuasive ( $\$ 39)$, and that the board's decision in this case was in line with decision C-34/10 (-44).

Of further interest is the still pending appeal T 1808/13, which was filed in August 2013. It concerns Brüstle's European patent EP-B-1040185, which corresponds to the German patent that was the subject of the reference from the $\mathrm{BGH}$ to the CJEU as case C-34/10, discussed extensively above. As noted in footnote 6 above, the BGH eventually allowed the case with a proviso to claim 1 reading "wherein no isolated purified precursor cells from human embryonic stem cells are encompassed during the generation of which embryos have been destroyed." In the corresponding European case, the opposition division of the EPO decided to revoke the patent for added subject matter because of the presence of a proviso of similar wording. It is that decision that is now on appeal (also to Technical Board 3.3.08). It remains to be seen how the case will progress, as the original opposition to the patent (filed by Geron Corporation) was withdrawn in March 2014, although the patentee's appeal against the revocation that resulted from Geron's opposition is still pending. On the basis of T 2221/ 10 , if the appeal on added subject matter is successful, a further confirmation of the approach of the CJEU in Brüstle (C-34/10) might be expected.

A lesson to be drawn from these two cases is that practitioners should consider, when draft- 


\section{A. Sheard}

ing cases destined for the EPO, whether it is feasible to insert at the outset basis for a possible future disclaimer to avoid the exception from patentability embodied in Rule 28(c) EPC.

\section{CONCLUDING REMARKS}

The law that governs the patentability of stem cell technologies in Europe is complex, at least insofar as the stem cells are embryonic in origin. It has a convoluted genesis and is overlaid with case law from the CJEU, the EPO, and national courts, not all of which have historically taken the same approach, although the CJEU and EPO now appear to be aligning. Furthermore, the law deals with differing policy aims that are difficult to reconcile. With the relevant patentability exception being construed broadly, it is hard to say that the balance is currently in favor of the policy of encouraging research. On the other hand, the patentability prospects are brighter for stem cells_-even human stem cells_-of nonembryonic origin, as may be the prospects for human stem cells of embryonic origin with a 2008 or later priority date, at least pending clarification from the EPO Boards of Appeal.

\section{REFERENCES}

Chung Y, Klimanskaya I, Becker S, Li T, Maserati M, Lu S-J, Zdravkovic T, Ilic D, Genbacev O, Fisher S, et al. 2008. Human embryonic stem cell lines generated without embryo destruction. Cell Stem Cell 2: 113-117.

Kamstra G, Döring M, Scott-Ram NR, Sheard AG, Wixon HR. 2002. Chapter 1-Purpose. In Patents on biotechnological inventions: The EC Directive, pp. 1-8. Sweet \& Maxwell, London.

Schlich GW. 2013. Getting everything decided at first Instance at the EPO. epi Information 3/2013: 103-106 (see www.patentepi.com/uploads/media/2013_03_epi_ info.pdf).

Schlich GW, Hill L. 2013. Stem cell patents in Europe-No end to the waiting? CIPA 240-244 (http://www.schlich .co.uk/Stem_Cells_June2013.html). 


\title{
$\&_{\mathrm{CSH}}^{\infty} \&$ Cold Spring Harbor

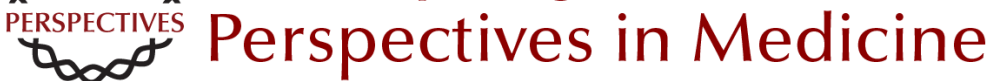

\section{Patenting Stem Cell Technologies in Europe}

\author{
Andrew Sheard
}

Cold Spring Harb Perspect Med 2015; doi: 10.1101/cshperspect.a021089 originally published online November 13, 2014

\section{Subject Collection Intellectual Property in Molecular Medicine}

Patentability of Stem Cells in the United States Sarah E. Fendrick and Donald L. Zuhn, Jr.

Inventorship and Authorship Antoinette F. Konski and Linda X. Wu

The Patentability of Stem Cells in Australia Jenny Petering and Prue Cowin

Impact of America Invents Act on Biotech Intellectual Property

Amanda Murphy, Michael Stramiello, Jonathan Stroud, et al.

Introduction to Intellectual Property: A U.S.

Perspective

Amanda Murphy, Michael Stramiello, Stacy Lewis, et al.

The Role of Regulatory Agencies and Intellectual Property: Part I

Kevin E. Noonan

Canada's Patented Medicines (Notice of Compliance) Proceedings and Intellectual

Property

Henry Bian and Conor McCourt

Patentability of Genes: A European Union

Perspective

Paul Cole
The Impact of Myriad on the Future Development and Commercialization of DNA-Based Therapies and Diagnostics

Michele Wales and Eddie Cartier

Protecting Traditional Knowledge Related to

Biological Resources: Is Scientific Research

Going to Become More Bureaucratized?

Prashant Reddy and Malathi Lakshmikumaran

Protecting Trade Secrets in Canada

Noel Courage and Janice Calzavara

Inherent Anticipation in the Pharmaceutical and

Biotechnology Industries

Michael Goldman, Georgia Evans and Andrew Zappia

The Role of Regulatory Agencies and Intellectual

Property: Part II

Kevin E. Noonan

Baseball Bats and Chocolate Chip Cookies: The Judicial Treatment of DNA in the Myriad Genetics Litigation lan Binnie and Vanessa Park-Thompson

The Impact of Myriad and Mayo: Will

Advancements in the Biological Sciences $\mathrm{Be}$

Spurred or Disincentivized? (Or Was Biotech

Patenting Not Complicated Enough?) Jennifer Gordon

Trade Secrets in Life Science and Pharmaceutical Companies

Tara Nealey, Ronald M. Daignault and Yu Cai

For additional articles in this collection, see http://perspectivesinmedicine.cshlp.org/cgi/collection/ 